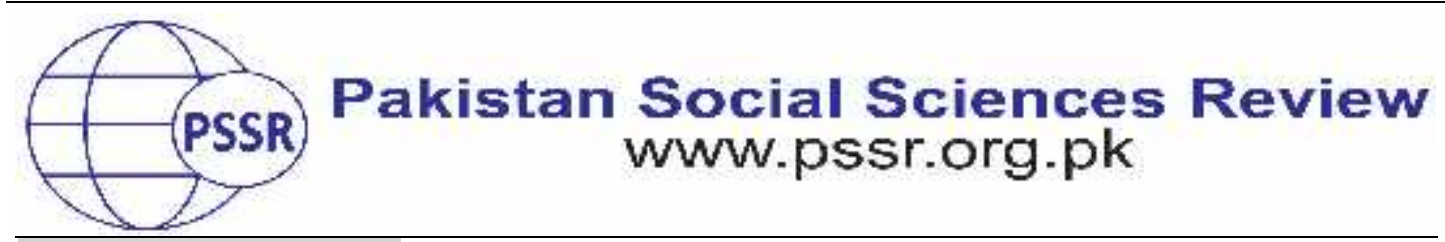

RESEARCH PAPER

\title{
Forensic Investigation of Road Traffic Accident Cases in Pakistan and Types of Physical Evidence
}

\author{
Khurram Faizan ${ }^{1}$ Dr. Adeel Abid ${ }^{2}$
}

1. Ph.D. Scholar, School of Law, University of Karachi, Karachi, Sindh, Pakistan

2. Assistant Professor, Dadabhoy Institute of Higher Education, Main Campus, Karachi, Sindh, Pakistan

\begin{tabular}{|c|c|}
\hline PAPER INFO & ABSTRACT \\
\hline Received: & Road accident is an eminent, socio-economic, and felonious \\
\hline August 11, 2021 & problem in all developed and under-developed countries. The \\
\hline Accepted: & dynamics and significance of road accidents are changing day by \\
\hline ber 11, 2021 & day and it has not been attracted sufficient attention from \\
\hline Onl & modern sciences. Pakistan being an underdeveloped country is \\
\hline $\begin{array}{l}\text { Keywords: } \\
\text { Forensic Science, } \\
\text { Road Accident, } \\
\text { Vehicles, } \\
\text { Physical Evidence }\end{array}$ & $\begin{array}{l}\text { far from the advanced traffic management system to curb the } \\
\text { increasing score of accidents. Notwithstanding the recent } \\
\text { advanced improvements in confronting the road safety } \\
\text { challenges, the situation is alarming in Pakistan due to the old } \\
\text { and routine methodology of investigation in road accident cases. }\end{array}$ \\
\hline $\begin{array}{l}\text { *Corresponding } \\
\text { Author }\end{array}$ & $\begin{array}{l}\text { In this study, attention has been drawn towards the lack of } \\
\text { advanced techniques, highlighting research gaps and types of } \\
\text { physical evidence in road accident cases in Pakistan using the }\end{array}$ \\
\hline $\begin{array}{l}\text { kf.khan1986@gmai } \\
\text { l.com }\end{array}$ & $\begin{array}{l}\text { data collected from primary (survey and interviews) and } \\
\text { secondary (government and NGO) sources. The findings show } \\
\text { that flaws in substantial and procedural laws, the inability of } \\
\text { investigation officers, corruption in government institutions, and } \\
\text { non-collection of physical evidence from crime-scene are the } \\
\text { main reasons for the deteriorating situation of road safety in the } \\
\text { country. }\end{array}$ \\
\hline
\end{tabular}

\section{Introduction}

Approximately 1.25 million fatalities occur worldwide in road accidents yearly and the non-fatal injuries are higher in number vis-à-vis (Wegman, 2017), adversely affecting the safety and health of injury survivors and their families (Donaldson et al., 2009). To increase road safety, improvement is required into preventable causes of Road Traffic Accidents (RTA). After an accident, the law set into motion by lodging First Information Report (FIR) which is the main source of leading a criminal case. Serious apprehensions have been upraised by academics and the authorities of road safety over the trustworthiness of police-reported contributing factor data (Graves et al., 2014), but no attempt has been made or a little to investigate 
this matter empirically. This article purposes to contribute substantiating this crack by investigating the RTA cases through advanced techniques.

Police officers attending RTA cases are not only required to provide a subjective assessment of the factors that they believe contributed to the collision but also forensic teams should visit the crime scene to evaluate the reasons for RTA. The police officers who initially visit the crime scene are likely to retain valuable information into the causes of RTA involving old and new techniques. Simultaneously the assessments of forensic experts are likely to be more accurate than the views of the police officers (who depend on stereotype methods of criminal investigations). In fact, the reports of forensic experts about some accident causes may be more accurate than the views of police officers based on road accident records, because some aspects are difficult to authenticate or substantiate at the roadside and thus may be examined in forensic labs.

The grounds of RTA are complex but broadly depend on road engineering and the characteristics of drivers. Inexperience (McCartt, Shabanova \& Leaf 2003), risk-taking behaviors (Rolison et al., n.d.), and skill level (McGwin \& Brown, 1999) may be implicated in the RTA by young drivers compared with drivers of other ages. Investigations of RTA cases associated with driving recklessly, traffic violations, excessive speed, drugs, and alcohol consumption are common factors. The consistency in the RTA is due to weak legislation and the non-conviction of perpetrators due to defective investigation. Collectively, these findings support the improvement in road safety measures and the use of modern and advanced techniques to curb the RTA gradually. Further, these contributing factors appear to be influenced by corrupt officials (Malik \& Qureshi, 2021), defective investigation (Rajput \& Rajput, 2020) by old methods, and road hazards.

Memorizing the road accident details by experienced police officers may be better but the collection of evidence through modern and advanced ways may enable them to give concrete and affirm evidence in the Court. The Investigation Officer (I/O) of RTA must manage simultaneously a multitude of cognitively demanding tasks like securing pieces of evidence (blood-stained mud, clothes of victim, broken pieces of vehicle, etc), writing memos, and attending to injured persons at the hospital. He also needs to record statements of eyewitnesses, if any. This multifaceted task indicates that before concluding the evidence and detail report some time may pass, hypothetically affecting the trustworthiness of the report of $\mathrm{I} / \mathrm{O}$ when details must be recalled from memory during evidence in the Court. It is an admitted fact that RTA cases are based on circumstantial evidence and chain of custody of physical evidence must be ensured to prove a case in the Court of law.

In the current research, data was obtained from primary and secondary sources and compared with the legal aspects and available advanced techniques. A big variation was found in reported and unreported fatal cases by government 
institutions and NGOs. The outcome of the research is the examination of fatal accident trends in society, the available modern techniques to redesign the investigation method through forensic methodology, collection of physical evidence from the crime scene in a particular manner suggests that RTA rates reduce over time as a result of skill development and perceives the correlation between accidents and explicit measures of human activity.

\section{Literature Review}

Continuous increase of RTA in metropolitan cities is turning into a great concern which diverts as much as 90,000 lives expansion to human destructions. Reasons for RTA can be well implied with the help of RTA investigation information, which can introduce hints to many issues of RTA (VALLI, 2005). It is believed among researchers that Smeed has committed his examination in the era of RTA and record weighty work on the assessment of RTA and auxiliary scrutinized the distinctions in the models of RTA in different countries and their explanations (Smeed, 1968).

A comprehensive case study on RTA in Israel is accomplished (Hakkert, 1972). Applying employment and population data (Partyka, 1984) built up simple models with a viewpoint to recognize the diversity of factors distressing the supplement of crashes in under-developed countries. The Smeed's method is not concerned with all countries (Andreassen, 1985). Mekky applied the time series data for his study and planned the consequences of a quick magnify in motorization stages on RTA in several under-developed countries (Mekky, 1985). The total crash patterns in Delhi have been comprehended (Mohan, 1984). (G. D. Jacobs \& Cutting, 1986) strived more to modernize the association based on earlier studies. (Fieldwick, R., \& Brown, 1987) worked out the investigation methods on the effect of speed restrictions in RTA. According to them in urban and rural areas speed limits have a substantial effect on road safety.

Minter deliberates the significance of the two models (Wright and Towell) for road safety hazards and extended a model for calculating the RTA in the United Kingdom (Minter, 1987). Valli and Sarkar scrutinized the discrepancies in the arrangement of RTA in different states of India (VALLI, 1993). Emenalo set up the propensity arches for the RTA, casualties, and other pertinent numbers for Zambia (Emenalo et al., 1977). Valli and Sarkar also built a RTA model by adopting the added limit of road span (Valli, P.P. and Sarkar, 1997). (Ameen \& Naji, 2001) presented an extensive modeling policy to cast RTA victims in Yemen.

The dilemma of RTA in African and Asian countries is severe in nature (G. D. Jacobs \& Cutting, 1986). Fatality rates (per certified vehicle) are very high comparatively with those in developed states as well as in North America and Europe 
while the environments are generally civilizing but numerous developing countries facade a deterioration condition (G. Jacobs, 1995).

At present, the population of Pakistan is more than 200 Million while the traffic flow is also increasing proportionately which emphasizes improvement in the transportation sector with modern technology in line with the international emergence ("Road Fatalities," 2016). The use of new modern technologies will also help the country in a medical emergency as several patients die in ambulances due to traffic jams or road hazards (Martinez et al., 2010). The researchers have gone through the case laws on the subject issue but unfortunately, no work is found in Pakistan. Even till date, the use of forensic science and expert reports are not covered by proper legislation (Shah, 2021).

\section{Material and Methods}

\section{Analysis of Primary Data}

A questionnaire was designed and public survey was conducted to understand the key reasons of RTA, out of 67 respondents, there were 44 government officials, 7 were judges/lawyers, 4 were law students and there were 12 who belonged to other categories.

\section{Results and Discussion}

Table 1

\begin{tabular}{cccc}
\hline \multicolumn{4}{c}{ Who does wrong in most of the road accidents? } \\
\hline & Observed N & Expected N & Residual \\
\hline Dilapidated Road & 7 & 16.3 & -9.3 \\
\hline Driver & 32 & 16.3 & 15.8 \\
\hline Rider & 24 & 16.3 & 7.8 \\
\hline Pedestrian & 2 & 16.3 & -14.3 \\
\hline Total & 65 & & \\
\hline
\end{tabular}

$\mathrm{H}_{0}$ : People's opinions are equally likely for the given reasons of dilapidated road, driver, rider and pedestrian for road accidents.

$\mathrm{H}_{\mathrm{a}}$ : People's opinions are not equally likely for the given reasons of dilapidated road, driver, rider and pedestrian for road accidents.

Table 2

\begin{tabular}{cccc}
\hline \multicolumn{4}{c}{ Are you satisfied with the driving license issuing system? } \\
\hline & Observed N & Expected N & Residual \\
\hline No & 53 & 32.5 & 20.5 \\
\hline Yes & 12 & 32.5 & -20.5 \\
\hline
\end{tabular}




\section{Total 65}

$\mathrm{H}_{0}$ : There was no significant difference in satisfaction level for the current driving license system.

$\mathrm{H}_{\mathrm{a}}$ : There was a significant difference in satisfaction level for the current driving license system.

Table 3

\begin{tabular}{cccc}
\hline & \multicolumn{3}{c}{ The traffic laws should be more strict? } \\
\hline & Observed N & Expected N & Residual \\
\hline No & 6 & 21.7 & -15.7 \\
\hline Maybe & 4 & 21.7 & -17.7 \\
\hline Yes & 55 & 21.7 & 33.3 \\
\hline Total & 65 & & \\
\hline
\end{tabular}

$\mathrm{H}_{0}$ : There was no significant difference in people's opinion that traffic laws should be more strict.

$\mathrm{H}_{\mathrm{a}}$ : There was a significant difference in people's opinion that traffic laws should be more strict.

Table 4

All the vehicle manufacturing companies should be bound to apply least international safety standards in all vehicles?

\begin{tabular}{cccc}
\hline & Observed N & Expected N & Residual \\
\hline Maybe & 1 & 32.5 & -31.5 \\
\hline Yes & 64 & 32.5 & 31.5 \\
\hline Total & 65 & & \\
\hline
\end{tabular}

$\mathrm{H}_{0}$ : There was no significant difference in people's opinion that all the vehicle manufacturing companies should be bound to apply the least international safety standards in all vehicles.

$\mathrm{H}_{\mathrm{a}}$ : There was a significant difference in people's opinion that all the vehicle manufacturing companies should be bound to apply the least international safety standards in all vehicles.

Since the data was qualitative in nature and measured on a nominal scale, the researchers used the chi-square goodness of fit test to check the hypotheses. The significance threshold was set at 0.05 . 
Table 5

Chi-square goodness of fit test

\begin{tabular}{lcccc}
\hline \multicolumn{5}{c}{ Test Statistics } \\
\hline & Hypothesis 1 & Hypothesis 2 & Hypothesis 3 & Hypothesis 4 \\
\hline $\begin{array}{c}\text { Chi- } \\
\text { Square }\end{array}$ & $36.723^{\mathrm{a}}$ & $25.862^{\mathrm{b}}$ & $77.015^{\mathrm{c}}$ & $61.062^{\mathrm{b}}$ \\
\hline $\mathrm{df}$ & 3 & 1 & 2 & 1 \\
\hline $\begin{array}{l}\text { Asymp. } \\
\text { Sig. }\end{array}$ & $<0 . .001$ & $<0.001$ & $<0.001$ & $<0.001$ \\
\hline $\begin{array}{l}\text { a. } 0 \text { cells }(0.0 \%) \\
\text { frequency is } 16.3 .\end{array}$ \\
$\begin{array}{l}\text { b. } 0 \text { cells }(0.0 \%) \text { have expected frequencies less than 5. The minimum expected cell } \\
\text { frequency is 32.5. }\end{array}$ \\
$\begin{array}{l}\text { c. } 0 \text { cells }(0.0 \%) \text { have expected frequencies less than 5. The minimum expected cell } \\
\text { frequency is 21.7. }\end{array}$ \\
\hline
\end{tabular}

The chi-square test statistic and their p-values for the specified hypotheses were reported in Table-5. Hypothesis 1 had a Chi-square test statistic of 36.723 and a $\mathrm{p}$-value $<0.001$. The P-value for hypothesis 1 was less than 0.05 , which was the conventional level of significance. It meant that the null hypothesis had been rejected. As a result, the researchers concluded that people's opinions are not equally likely for the stated explanations of a dilapidated road, a driver, a rider, and a pedestrian for road accidents. Table- 1 shows that, in the perspective of the people, drivers were the primary cause of road accidents, as evidenced by the highest observed count.

Hypothesis 2 had a Chi-square test statistic of 25.862 and a p-value $<0.001$. The P-value for hypothesis 2 was less than 0.05 , which was the conventional level of significance. It meant that the null hypothesis had been rejected. As a result, the researchers concluded that the present driving license system had a considerable disparity in satisfaction levels. Table- 2 reveals that, in the opinion of the people, the existing driving license issuance system is ineffective, as indicated by the highest observed count.

The Chi-square test statistic for Hypothesis 3 was 77.015, with a p-value < 0.001 . Hypothesis 3 had a P-value of less than 0.05 , which was the standard level of significance. It meant that the null hypothesis was no longer valid. As a result, the researchers concluded that there was a significant difference in people's opinions regarding the strictness of traffic laws. Table- 3 reveals that, in the opinion of the people, traffic laws should be more strict, as indicated by the highest observed count.

The Chi-square test statistic for Hypothesis 4 was 61.062, with a p-value < 0.001 . Hypothesis 4 had a P-value of less than 0.05 , which was the standard level of significance. It meant that the null hypothesis was no longer valid. As a result, the researchers concluded that there was a significant difference in people's opinion that all the vehicle manufacturing companies should be bound to apply the least 
international safety standards in all vehicles. Table- 4 reveals that, in the opinion of the people, all the vehicle manufacturing companies should be bound to apply the least international safety standards in all vehicles, as indicated by the highest observed count.

\section{Analysis of Secondary Data}

The researchers collected secondary data from different authentic sources to understand the patterns of accidents in the province of Sindh, Pakistan. The data was collected from Edhi Center, Sind High Court, Driving License Department, Sindh Police Department and Shaheed Muhtarma Benazir Bhutto Institute of Trauma.

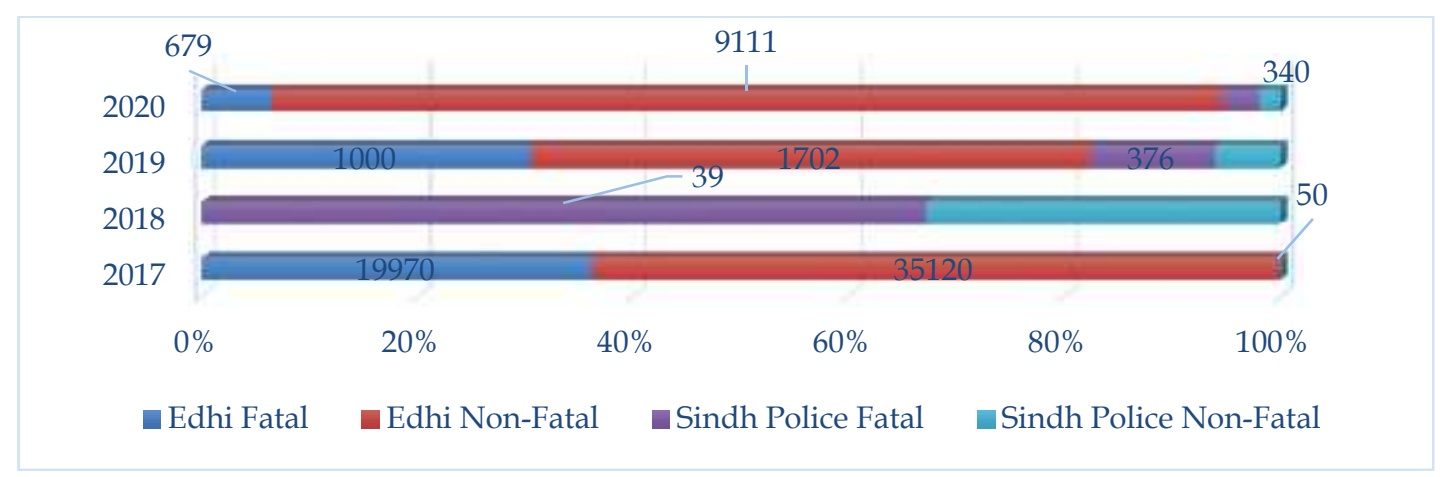

Figure 1 Fatal and Non-fatal Accidents

Figure-1 presented the data of fatal and non-fatal accidents collected from the Edhi Center and Sindh Police Department for the years (2017-2020). It can be observed from this chart that there was a huge difference between the number of accidents reported by the Edhi Foundation and Sindh Police. Despite the fact that the Medico-Legal Officer (MLO) must inform to police about RTA cases and it is the responsibility of the State to lodge FIR where Legal Heirs of the deceased do not come forward to initiate legal proceedings. This non-compliance of Section 154 of the Criminal Procedure Code, 1898 (Cr.P.C.) encourages the drivers to drive vehicles fearlessly.

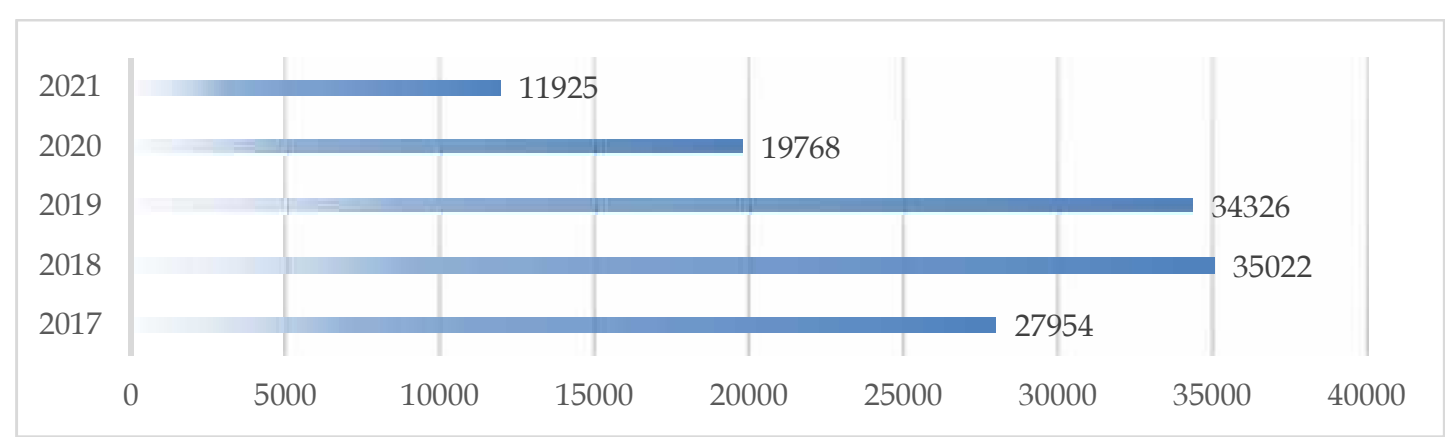

Figure 2 Accident cases reported to SMBBIT 
Figure-2 exhibited the data of number of accidents recorded at Shaheed Muhtarma Benazir Bhutto Institute of Trauma (SMBBIT). It is observed that number of accidents cases reported at SMBBIT decreased gradually from 2018 to 2021. This data represents only one statutory body/government hospital while the other major government hospitals like Jinnah Post Graduate Medical Center (JPMC), Abbasi Shaheed Hospital (ASH), etc. refused to share their data. These numbers are higher than the data provided by Edhi Foundation, as other NGOs like Chhipa, Aman Foundation (they also failed to share their data publically), etc. are also working in the province of Sindh and they also shift the RTA cases to different government and private hospitals.

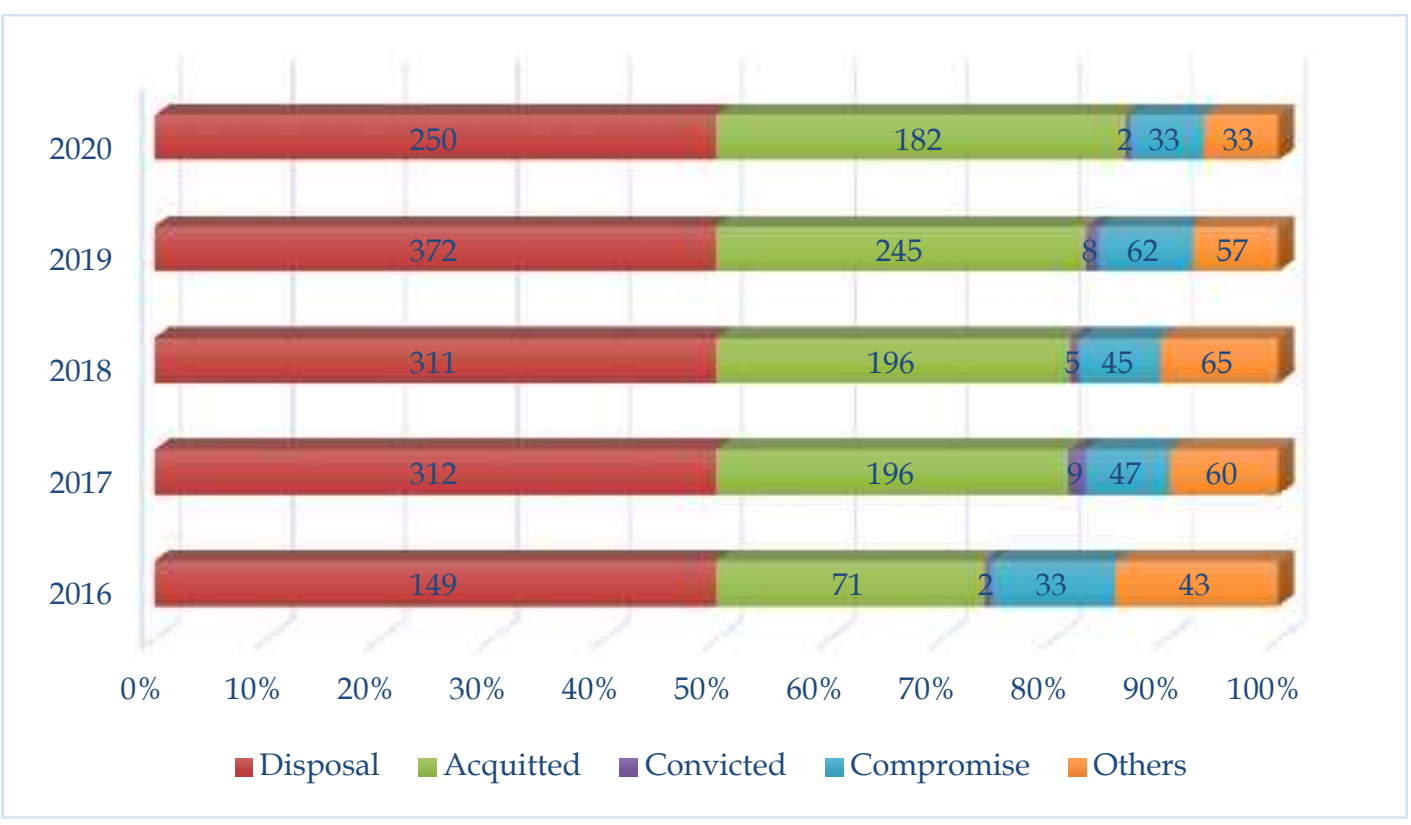

Figure 3 Judicial cases decided by District Courts

Figure-3 provided the data collected from Sindh High Court. This chart exhibited the cases that were decided by the District Judiciary Sindh for the period of 2016-2020. The astonishing figures clearly indicate that the defective investigation is one of the causes of lesser conviction in RTA cases. Data shown in Figure 3 only relates to RTA cases wherein people(s) die and the accused persons either got acquitted or LRs entered into a compromise with them. This leniency is available in Section 320 of the Pakistan Penal Code, 1860 (PPC) being a bail-able and compoundable offense due to which vehicular homicide has not been considered a serious crime so far in Pakistan. 


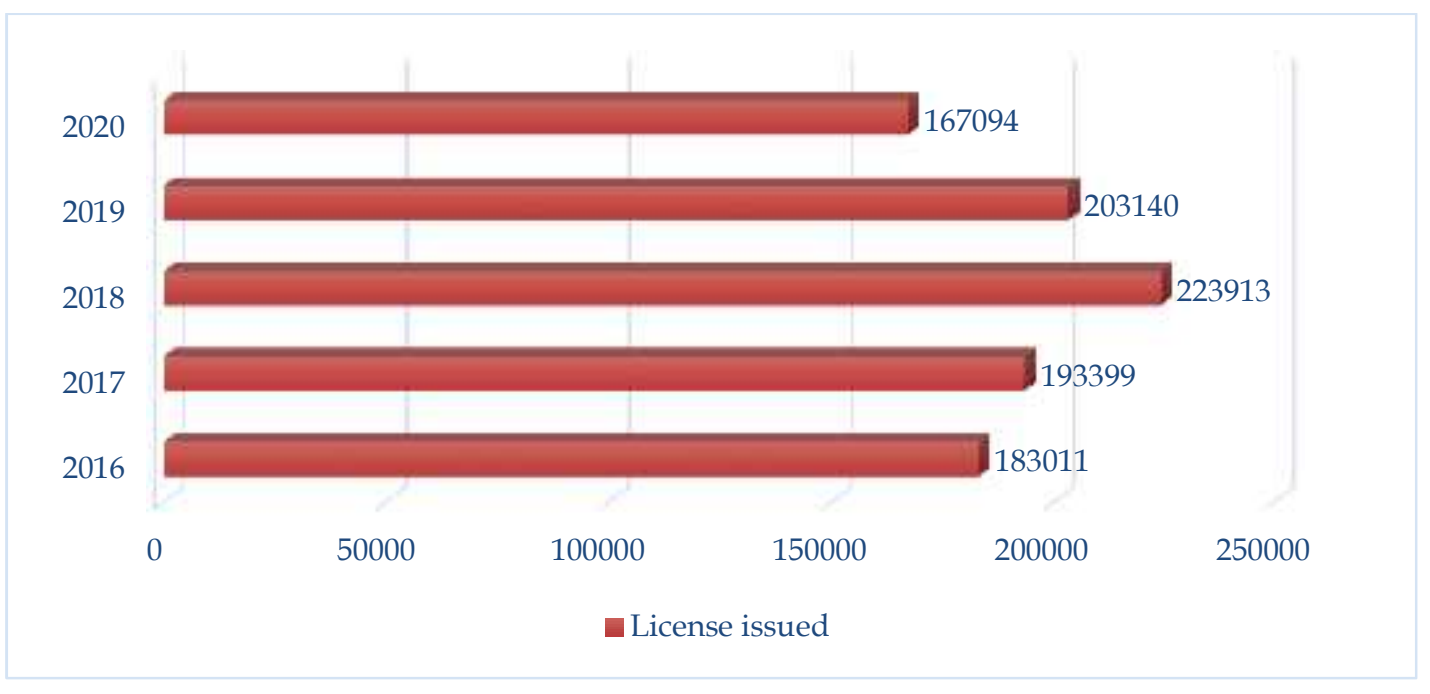

Figure 4 Driving Licenses Record

Figure-4 shows the data for driving licenses that were issued between 2016 to 2020 by the Sindh Police, Driving License Branch. This graph shows that the maximum number of licenses were issued to the people but on the contrary, the figures reflected in Figures 1 and 2 clearly show that the fatality rate is high which points the finger upon irregularity in the driving license issuing process. It is necessary to mention here that in past even blind people issued driving licenses (Sar e Aam - 29th April 2016 Blind man with driving license in Pakistan fake system YouTube n.d.).

The findings are two major reasons for increasing score of RTA cases, (i) Nonavailability of exhaustive substantial law coupled with procedural law to deal with the RTA cases and (ii) Inefficiency of government departments and officials working therein to use the advanced techniques for RTA cases, for which the main reasons are corruption and inability.

\section{Discussion}

Hit and run is a general phenomenon in all crashes. In most of cases, especially in Pakistan, the drivers used to hit someone and run with the vehicle or sometimes fled away leaving behind the vehicle because they (especially commercial drivers) know the vehicle owner will recover his vehicle. In such cases, the ocular evidence is exceptional as people avoid to give evidence in Pakistan. The second option is circumstantial evidence which should be consistent, concrete and without any reasonable doubt. The rule of circumstantial evidence is that failure of the prosecution to prove one link of the chain of circumstances would destroy all links (Gillani, 2003). It is further observed in the cases of commercial vehicles that the 
vehicle owner to save himself and vehicle, produces any other person having a valid driving license and he can easily get bail and acquit from charge ultimately. In the above position, the modern techniques of forensic science are very helpful to apprehend the actual perpetrator.

When we are discussing the road accident it would be appropriate to go through the relevant laws of the road accident in Pakistan and observations of the Apex Courts in this behalf from time to time. It is important to refer here that in number of cases the drivers of commercial vehicles are driving the vehicles without driving licenses or invalid commercial driving license. In such a situation the Hon'ble High Court of Sindh recently hold in a case (Akbar, 2020) that the police is not complying with the dicta laid down in case (Jafferi, 2005) whereby the police was directed to implead the owner of the vehicle as co-accused. In such cases where the driver is underage or driving the vehicle without a license then the owner of the vehicle should be tried as co-accused being responsible of Qatal-bis-Sabab. Under that provision of law, if anybody commits Qatl-bis-Sabab then he is liable for punishment to Diyat (Blood Money) u/s 321 and 322, PPC. The offenses punishable under sections 320,427 and 279, P.P.C. are bailable whereas the offenses fall under section 322, PPC is non-bailable.

Since the requirement of section 320 of the PPC is based on the two ingredients i.e. rash and negligent, but in the present circumstances and complicated law of evidence, it is impossible to prove that a driver was driving the vehicle rashly and negligently as mere 'high-speed' does not fulfill the criteria of rashness and negligence when the effective braking system are installed in the vehicles which require no time to stop the vehicle (Seth, 2012). The Hon'ble Peshawar High Court observed this point in some other context as the facts and circumstances of every case are different but it cannot be treated as a precedent that excludes the rashness and negligence from each road accident case. In such a scenario the forensic science can help out the prosecution to ascertain whether the driver was driving the vehicle at normal speed with due care or at high speed in a rash and negligent manner. The observation of the Hon'ble Courts might be compromised to the extent that there is no formula to calculate the speed of the vehicle. At this juncture, the following formula may be adopted not only to ascertain the speed but also the actual position of the vehicle when and where the driver applied the brakes:-

"As a consequence, the most important variables, which determine the distance a car takes to skid to a halt, are speed and the nature of the surface of road. Thus if the coefficient of friction $(\mu)$ between tires and the road surface can be measured then a reliable estimate of the speed $(v)$ can be calculated from the length of the tire marks (l). If a car is skidded to a halt from a known speed then:

$$
\mu=V^{2} / 2 g l
$$


leaving

Where $g$ represents the acceleration due to gravity and then the speed of the car the skid marks is given by:

$$
V=\sqrt{ }(2 \mu g l)^{\prime \prime}
$$

(Forensic Investigation of Road Accidents-II Module Tag FSC_P1_M20, n.d.)

Unfortunately, our institutions are not properly equipped with the modern techniques of forensic science. We are examining the vehicles in forensic labs only in vehicle theft cases. However, it may be useful in road accident cases as several times drivers run away with vehicles after an accident. Usually, the Motor Vehicle Inspector (MVI) inspects the vehicles in road accident cases but he only prepares his report on the basis of his average assessment and his calculations are based on presumptions, which creates doubt and this doubt ultimately goes in favor of the accused (Sidhu, 2017). The reports of forensic experts are not covered under Article 59 of the Qanun-e-Shahadat Order, 1984 and Section 510 Cr.P.C. (Shah, 2021).

It is important to mention here that to apprehend the actual perpetrator and to secure the primary evidence the investigation team should reach the crime scene as early as possible and cordon off the place of occurrence. First of all the MVI should inspect the vehicle as the role of MVI is covered under the law in road accident cases. The forensic team should array the following points to commence collecting evidence:-

i. To identify the vehicle in a hit and run case.

ii. Secure the finger and palm prints of the driver (if the driver left his vehicle and fled away).

iii. Whether it was a general road accident or an attempt to hide any other crime.

The sources of forensic evidence from the place of occurrence may be as under:-

- Complete photography of the crime scene.

- Road marks corresponding to tire impressions of all wheels, may be found either at sharp turns or when the vehicle reversed.

- Damaged or wrecked parts of the vehicle.

- The vehicle may be one or more, its position, direction or type.

- Lubricants or greases.

- The paint/color marks or chips.

- Broken glass parts of various sizes or shapes.

- The marks of skidding. 
- The dust/mud, rubble, wreckage, dirt, caked, dropped from the vehicle of a suspect at the time of incident.

- Drag marks of the material loaded on suspect vehicle.

- Vehicular and personal articles left at the place of occurrence (e.g. number plate, ID card, Wallet etc.)

In many cases, the vehicle involved in the crash may carry hints from the place of occurrence or from the collided vehicle and the victim. The following pieces of evidence may be found on the suspect's vehicle:-

- Bloodstain, hairs or skin tissues of the victim.

- Finger and palm prints, tool-marks and fabric prints.

- Paint/color, lubricants and greases, shattered glass of the vehicle which was hit and attached from the suspect's vehicle.

- Little broken parts or pieces of the vehicle or the articles hit.

- Residue, mud and soil from the place of incident, from the driver or victim.

- Proof identified with manipulation in paint and on the registration number plate, Chassis and Engine numbers.

Prior to the assessment of evidence, it is necessary to make it possible to collect the evidence in proper manners so that no lacuna be left e.g. click photos and make memo of sketches of the scene first without moving anything from the place of incident. The photographs and memo of sketches may be prepared in a manner that the location of incident can be shown by including all directions of the scene, the famous landmarks and/or any hoarding boards. The identity of the vehicles should be cleared in the pictures. Before moving the vehicle from the place of incident to the police station/forensic laboratory, note down the mileage of the speedometer, the temperature of the vehicle, the surrounding weather's temperature and the liquid in the radiator. Note the fuel in the tank, look at the entire region for any actual hints and gather any loose proof which is probably about to become mixed up on the way. Inspect the other parts of the vehicle thoroughly like brakes, horns, lights, airbags etc. All the secured pieces of evidence must be documented in notes/memos form, pictures and then sealed properly/securely in glass bottles or cellophane envelopes based upon the form of the evidence. To avoid any contemplation in the evidence all officials should wear hand gloves and Personal Protective Equipment (PPE).

Speed is a key factor in accident cases where drivers drive the vehicle negligently and speedily. However, some Courts observed (as mentioned above) that speed is not the key factor for an accident and no formula is available to calculate the speed. The thorough forensic analysis enables the investigation team to calculate the speed of the vehicle at the time of the incident and the following may be observed:-

- The radius of curved scuff marks (when a driver loses control of the vehicle) 
- The extent of vehicle damage (the proportion of vehicle speed and damage)

- The length of skid marks (marks left by tires, no longer moving)

Furthermore, to avoid accidents in black spot areas the Geo-Fencing Based Avoidance Notification (Nayak et al., 2019) may help the commercial drivers to secure themselves so also others. Since the commercial drivers travel from one destination to others and these long and restless trips give them mental agony and fatigue. The latest development through modern forensic equipment may help out them to avoid such situations. The Geo-fencing (Sachin W. Rahate, 2016) in the blackspotted areas will help the commercial drivers to be attention as soon as they enter the radius of the black-spotted area. A voice-based notification will alarm the driver to reach near or entering in the black-spotted area so that he does not need to check the mobile again and again. The Global Positioning System (GPS) technology may be used to determine a virtual limit called as Geo-Fence and open-source Google APIs for setting the black spots on Google Maps. Firebase (Stonehem, 2016) may be utilized as a backend to store the information on continuous data sets for giving notice to vehicles moving towards the black spot. The Geo-Fenced regions are set apart at an adequate separation from the real clumsy zones to give warnings ahead of time. Important notices are given on the application, just if the driver is in the Geo-fenced region.

On 25th June 2017, an oil tanker traveling from Karachi to Lahore, carrying 4000 liters fuel, overturned at Bahawalpur, and fuel started to leak. The residents of the locality rushed to collect the fuel and in the meanwhile the same was exploded and about 153 died by burn and several received injuries (Zaheer Siyal, 2017). In case of a proper tracking system in the giant vehicles and safety alarms, the oil tanker could have been cordoned off soon after the incident. It is further observed that DNA technology is being used to identify burnt bodies. Generally, in massive crashes (Update, 2020) DNA is being used to match the DNA profile of the deceased with his family members which is a very costly way to do so while on the other hand, Forensic Dental Identification (Park, 2006) is a low-cost substitute for human body identification which may be used for the same results.

The use of GPS, Geo-fencing, sleep alarming device etc. may help the driver from any accident or securing evidence by a forensic team in the shape of DNA, Serology, vehicle examination etc. can assist the police to arrest the actual perpetrator or the forensic reports may assist the Courts to reach at just decision. Installation of cameras on the front screen of commercial vehicles may also make it possible to capture the actual moment, including but not limited to, speed of the vehicle, right of way, negligence on the part of pedestrian / other vehicles, driving lane etc. The installation of CCTV cameras on road may also help out to determine the mistake/negligence of both parties. The videography test report will also corroborate the other circumstantial and ocular evidence. The worst scenario is that in our 
country there is no specific forensic laboratory to deal with accident cases. Even there is no concept of forensic examination in accident cases, despite the fact, the ratio of death by road accident is very high than murder, rape or COVID-19 cases.

Furthermore, the forensic of the offending vehicle is also necessary to ascertain whether the vehicle was properly maintained or its safety functions i.e. SRS Airbags, Electronic Stability Control (ESC), Electronic Brake Distribution (EBD), Forward Collision Warning, Anti-lock Braking System (ABS), Adoptive Headlights, Speed Limiters etc. were in working condition or not. In case of any defective or substandard safety function, the manufacturing company may also be arrayed in criminal proceedings especially when a life has been lost due to non-availability or non-functionality of such safety functions (Iqbal, 2011).

\section{Conclusion}

The use of advanced technologies and modern forensic science can be helpful to apprehend the actual culprits and can change the obstacles of old investigation techniques. At present no forensic examination is being conducted in all accident cases including massive crashes. The laws related to road accidents are outdated. No changing is found in criminal investigation, trial, and punishment despite the increasing rate of road accident cases and repeated directions of the Hon'ble Apex Courts. Big variation is found in road accident cases reported by Edhi Foundation, patients provided medical facilities in the hospital, FIR lodged by police, and cases decided by the Courts. No social or financial help is being provided by the State which leaves a negative impact to the injury survivors or their family members. A comprehensive law is required to make for road accidents to cover up all deficiencies in one code. 


\section{REFERENCES}

Akbar, N. (2020). Jalaldin Versus The State and another. In P.CR.L.J. [SINDH] (p. 451). www.pakistanlawsite.com

Ameen, J. R. M., \& Naji, J. A. (2001). Causal models for road accident fatalities in Yemen. Accident Analysis and Prevention, 33, 547-561. www.elsevier.com/locate/aap

Andreassen, D. C. (1985). Linking deaths with vehicles and population. Traffic Engineering and Control, 26(11), 547-549. https://www.safetylit.org/citations/index.php?fuseaction=citations.viewdetails\& citationIds[]=citjournalarticle_63483_19

Donaldson, L., Brooke, K., Review, S. F.-A. H., \& 2009, U. (2009). Orthopaedic trauma from road crashes: is enough being done? Australian Health Review, 33(1), 72-83. https://www.publish.csiro.au/ah/ah090072

Emenalo, S., Puustelli, M., Ciampi, A., \& \& H. J. (1977). Analysis of road traffic accidents data in Zambia. Accident Analysis $\mathcal{E}$ Prevention. https://www.sciencedirect.com/science/article/pii/000145757790046X

Fieldwick, R., \& Brown, R. J. (1987). Effect of speed limits on road casualties. Traffic Engineering and Control, 28(12), 635-640. https://www.safetylit.org/citations/index.php?fuseaction=citations.viewdetails\& citationIds[]=citjournalarticle_63394_19

Forensic Investigation of Road Accidents-II Module Tag FSC_P1_M20. (n.d.).

Gillani, S. M. H. (2003). Muhammad Aslam and others V. Khursheed alias BAGO and 3 others. In YLR [Shariat Court, AJEKK] (p. 2958). www.pakistanlawsite.com

Graves, F., Lloyd, D., Wilson, D., Mais, D., \& Deda, W. (2014). Reported Road Casualties Great Britain: 2013 Annual Report. https://trid.trb.org/view/1326318

Hakkert, M. L. and A. S. (1972). Some Factors Affecting the Increase of Road Accidents in Developing Countries. Accident Analysis and Prevention, 4(2), 117-133.

Iqbal, J. (2011). Dr. Sher Afgan Khan Niazi V. Ali S. Habib and others. In SCMR (p. 1813). www.pakistanlawsite.com

Jacobs, G. (1995). Costing road accidents in developing countries. OVERSEAS ROAD NOTE 10, 17-21.

Jacobs, G. D., \& Cutting, C. A. (1986). FURTHER RESEARCH ON ACCIDENT RATES IN 
DEVELOPING COUNTRIES. Accid. Anal. E Prev, 18(2), 119-127.

Jafferi, R. H. (2005). Atta Muhammad V. The State. In P.CR.L.J. [SINDH] (p. 1648). www.pakistanlawsite.com

Malik, N., \& Qureshi, T. A. (2021). A Study of Economic, Cultural, and Political Causes of Police Corruption in Pakistan. Policing: A Journal of Policy and Practice, 15(2), 14461462. https://doi.org/10.1093/POLICE/PAAA016

Martinez, F. J., Toh, C. K., Cano, J. C., Calafate, C. T., \& Manzoni, P. (2010). Emergency services in future intelligent transportation systems based on vehicular communication networks. IEEE Intelligent Transportation Systems Magazine, 2(2), 620. https:// doi.org/10.1109/MITS.2010.938166

McCartt, A. T., Shabanova, V. I., \& Leaf, W. A. (2003). Driving experience, crashes and traffic citations of teenage beginning drivers. Accident Analysis E Prevention, 35(3), 311-320. https:// doi.org/10.1016/S0001-4575(02)00006-4

McGwin, G., \& Brown, D. B. (1999). Characteristics of traffic crashes among young, middle-aged, and older drivers. Accident Analysis and Prevention, 31(3), 181-198. https://doi.org/10.1016/s0001-4575(98)00061-x

Mekky, A. L. I. (1985). EFFECTS OF RAPID INCREASE IN MOTORIZATION LEVELS ON ROAD FATALITY RATES IN SOME RICH DEVELOPING COUNTRIES. Accident Analysis \& Prevention, 17(2), 101-109. https://doi.org/https://doi.org/10.1016/0001-4575(85)90013-2

Minter, A. L. (1987). Road casualties-improvement by learning processes. Traffic $\begin{array}{lllll}\text { Engineering } \mathcal{E} & \text { Control, 28(2), }\end{array}$ https://www.safetylit.org/citations/index.php?fuseaction=citations.viewdetails\& citationIds[]=citjournalarticle_63434_19

Mohan, D. \& P. S. B. (1984). An analysis of road traffic fatalities in Delhi, India. Accident Analysis \& Prevention, 33-45. https://doi.org/https://doi.org/10.1016/00014575(85) $90006-5$

Nayak, B., Mugali, P. S., Rao, B. R., Sindhava, S., Disha, D. N., \& Swarnalatha, K. S. (2019). Geofencing-based accident avoidance notification for road safety. Advances in Intelligent Systems and Computing, 906, 379-386. https://doi.org/10.1007/978-98113-6001-5_30

Park, H.-K. (2006). The Application of the Forensic Dental Identification to Unidentified Individual Remains in Korea -Journal of Oral Medicine and Pain | Korea Science. Journal of Oral Medicine and Pain, 31(1), 27-26. https://www.koreascience.or.kr/article/JAKO200615536394429.page 
Partyka, S. C. (1984). Simple models of fatality trends using employment and population data. Accident Analysis and Prevention, 16(3), 211-222. https:/ / doi.org/10.1016/00014575(84)90015-0

Rajput, M. A., \& Rajput, M. R. (2020). Impact of Defective Investigation and Prosecution on $\quad$ Trial. Http:/Www.Sciencepublishinggroup.Com, 9(6), 265. https://doi.org/10.11648/J.SS.20200906.17

Road Fatalities. (2016). Energy And Transportation - Transport, 116. https:// doi.org/10.1787/888933336538

Rolison, J., Hanoch, Y., ... S. W.-J. of G., \& 2014, undefined. (n.d.). Risk-taking differences across the adult life span: a question of age and domain. Academic.Oup.Com. https://academic.oup.com/psychsocgerontology/articleabstract/69/6/870/545646

Sachin W. Rahate, D. M. Z. S. (2016). Geo-fencing Infrastructure : Location Based Service. International Research Journal of Engineering and Technology (IRJET), 3(11), 1095-1098. http://www.irjet.net/

Sar e Aam - 29th April 2016 Blind man with driving licence in pakistan fake system - YouTube. (n.d.). https://www.youtube.com/watch?v=IbfcWj_G9Qw

Seth, W. A. (2012). Yasir Arafat V.The State and another. In MLD [PSW] (p. 611). www.pakistanlawsite.com

Shah, S. M. A. (2021). Ali Haider alias Papu V. Jameel Hussain and others. In PLD (p. 362 SC). www.pakistanlawsite.com

Sidhu, M. I. (2017). Tauqeer Abbas Versus The State. In P.CR.L.J. [LHR] (p. 848). www.pakistanlawsite.com

Smeed, R. J. (1968). Variations in the patterns of accident rates in different countries and their causes. Traffic Engineering \& Control, 10, 364-371.

Stonehem, B. (2016). Google Android Firebase: Learning the Basics. https://books.google.com/books?hl=en\&lr=\&id=JeeODAAAQBAJ\&oi=fnd\&pg= PP10\&dq=Firebase+may+be+utilized+as+a+backend+to+store+the+information+ \&ots=tm6KwVSCHR\&sig=5L8kK01PStwm4jzX3dyrHdaeloE

Update, P. (2020). PIA AIR Plane Crash. https://www.piac.com.pk/corporate/pressreleases/1714-karachi-may-26-2020

Valli, P.P. and Sarkar, P. K. (1997). Models for road accidents in India. Highway Research 
Bulletin, Indian Roads Congress. 56, 1-11.

VALLI, P. P. (1993). Variation in the pattern of road accidents in different states and union territories in India. Proceedings of the Third National Conference on Transportation Systems Studies: Analysis and Policy. https://ci.nii.ac.jp/naid/10019045547/

VALLI, P. P. (2005). Road Accident Models for Large Metropolitan Cities of India. IATSS Research, 29(1), 57-65. https:/ / doi.org/10.1016/s0386-1112(14)60119-9

Wegman, F. (2017). The future of road safety: A worldwide perspective. IATSS Research, 40(2), 66-71. https:// doi.org/10.1016/j.iatssr.2016.05.003

Zaheer Siyal, M. I. and Z. A. S. (2017). Death toll from Bahawalpur oil tanker fire climbs to 153. Dawn. https://www.dawn.com/news/1341713 